\title{
Optimasi Pendistribusian Air dengan Metode North West Corner dan Metode Modified Distribution di PDAM Wae Manurung Kabupaten Bone
}

\author{
Rahmat Syam ${ }^{1, a)}$, Hisyam Ihsan ${ }^{1, b)}$, dan Muhammad Irham Muktamar ${ }^{1, c)}$ \\ ${ }^{1}$ Jurusan Matematika, Fakultas Matematika dan Ilmu Pengetahuan Alam \\ Universitas Negeri Makassar \\ a)rahmat.syam@unm.ac.id \\ b)hisyam.ihsan@unm.ac.id \\ c)muhammadirhammuktamar@gmail.com
}

\begin{abstract}
Abstrak. Penelitian ini membahas tentang optimasi pendistribusian menggunakan model transportasi yang menerapkan Metode North West Corner (NWC) dan Metode Modified Distribution (MODI) pada pendistribusian air di PDAM Wae Manurung kabupaten Bone. Data distribusi air diformulasikan dengan model transportasi, sehigga diperoleh keseimbangan model dengan penambahan variabel dummy dan tabel transportasi distribusi air, diperoleh solusi awal yang fisibel dengan perhitungan menggunakan Metode North West Corner. Berdasarkan solusi awal diperoleh solusi optimum dengan menggunakan Metode Modified Distribution. Hasil penelitian ini menunjukkan bahwa dengan penerapan Model Transportasi terjadi optimasi biaya distribusi air di Kabupaten Bone sebesar 52,22\% dibandingkan hasil perhitungan yang dilakukan oleh PDAM Wae Manurung Kabupaten Bone.
\end{abstract}

Kata Kunci: Optimasi, model transportasi, north west corner, modified distribution, distribusi air

\begin{abstract}
This study discusses the Optimization using types of transportation model that application North West Corner method (NWC) and Modified Distribution Method (MODI) on the stock of water in PDAM Wae Manurung Bone Regency. The water distribution data is formulated with a transportation model, so that in order to obtain the model is generated a balance model with addition dummy variable and export table water distribution, obtained a feasible initial solution by calculation using North West Corner method $(N W C)$. Based on a feasible initial solution obtained the optimum solution using the Modified Distribution Method (MODI). The results of this study indicate that with the application of the Transportation Model there was a optimization occurs in water distribution costs in Bone Regency in June 2019 of $52.22 \%$ compared to the calculation results by PDAM Wae Manurung Bone Regency.
\end{abstract}

Keywords: Optimization transportation model, north west corner, modified distribution, distribution water.

\section{LATAR BELAKANG}

Metode transportasi adalah metode yang digunakan untuk mengatur distribusi atau pendistribusian dari sumber ke tujuan untuk meminimkan biaya yang dikeluarkan. Distribusi adalah aktivitas menyalurkan produk baikbarang dan jasa dari produsen kepada konsumen. Salah satu barang yang biasanya didistribusikan yaitu air bersih sebagai sumber daya bagi kehidupan makhluk hidup (Zulkarnaen, 2020). 
Air bersih merupakan kebutuhan yang sangat vital guna mempertahankan kelangsungan hidup manusia, namun ketersediaan air bersih semakin sulit untuk didapatkan, dan bukan tidak mungkin akan menjadi langka di kemudian hari di karenakan banyaknya pencemaran lingkungan, seperti pencemaran air tanah, pencemaran aliran sungai karena sampah, dan pencemaran dari industri. Maka dibutuhkan badan usaha atau organisasi penyedia air bersih yang membutuhkan perencanaan, desain, cara pengumpulan, pemurnian, transmisi dan distribusi yang baik guna memenuhi setiap kebutuhan masyarakat akan air bersih yang semakin hari semakin bertambah kebutuhannya (Nelwan, dkk., 2013).

Distribusi air dalam suatu daerah biasanya dilakukan oleh organisasi atau perusahaan yang dinamakan Perusahaan Daerah Air Minum (PDAM). PDAM harus mempertimbangkan prinsip ekonomi, yaitu dengan pengeluaran yang minimal dapat menghasilkan kinerja yang maksimal dalam hal ini memenuhi kebutuhan konsumen akan air bersih (Nelwan, dkk., 2013). Salah satu PDAM yang melakukan distribusi di wilayah Kabupaten Bone yaitu PDAM Wae Manurung Kabupaten Bone.

PDAM Wae Manurung Kabupaten Bone didirikan pada tahun 1981 dengan tujuan menyelenggarakan pengelolaan air bersih dalam rangka meningkatkan kesejahteraan masyarakat yang mencakup aspek ekonomi, sosial dan kesehatan; dan untuk meningkatkan pelayanan umum yang berkualitas sesuai dengan harapan masyarakat. PDAM Wae Manurung terkendala pada beberapa masalah pendistribusian air kepada pelanggan saat krisis air bersih melanda sejumlah wilayah di kabupaten Bone saat musim kemarau 2019 (Dedhy S., 2018), polemik tarif PDAM kabupaten Bone (Trisna, 2018), dan perbaikanpipa transmisi wollangi ke rumah warga (Hammer, 2020).

Untuk mengoptimalkan pendistribusian air bersih salah satu cara dengan meminimalkan pengeluaran pada biaya distribusi (optimasi biaya). Salah satu metode untuk mengoptimalkan biaya distribusi adalah dengan menggunakan metode transportasi. Untuk menentukan solusi awal yang fisibel merupakan langkah pertama yang harus dilakukan. Untuk mendapatkan solusi awal yang fisibel ini dapat digunakan beberapa metode/kriteria yaitu: 1) Metode North West Corner (NWC); 2) Least Cost (LC); dan 3) Vogel's Approximation Method (VAM) (Asyhari, 2018). Kelebihan dari metode North West Corner adalah lebih cepat dalam pengambilan keputusan dan tanpa terlalu rumit dalam penempatan unit yang akan didistribusikan ke tempat permintaan (Chandra, 2016).

Setelah mendapatkan solusi awal dilanjutkan dengan mendapatkan solusi optimum, dengan menggunakan metode Stepping Stone dan metode Modified Distribution (MODI) (Asyhari, 2018). Kelebihan metode Modified Distribution (MODI) dibandingkan dengan metode Stepping Stone adalah penentuan sel pasti dancepat. Solusi dengan menggunakan metode MODI adalah suatu variasi metode Stepping Stone yang didasarkan pada rumusan dual (Aisyah, dkk., 2018).

Menyelesaikan kasus dalam masalah transportasi tidak menutup kemungkinan terdapat masalah seperti: ada jalan rusak, alternatif penyelesaian, permintaan yang tidak tepenuhi, degenerasi, redundansi, dan masalah transportasi tidak seimbang. Model Transportasi dikatakan seimbang apabila total supply (sumber) sama dengan total demand (tujuan).sebagaimana pada persamaan $\sum_{i=1}^{m} X_{i j}=\sum_{i=1}^{n} Y_{i j} \quad$, jika total supply (sumber) tidak sama dengan total demand (tujuan) maka model transportasi disebut sebagai model yang tidak seimbang (unbalanced). Setiap model transportasi dapat dibuat seimbang dengan cara memasukkan variabel artifisial (semu) (Asyhari, 2018).

Penelitian sebelumnya (Nelwan, dkk., 2013). telah menjelaskan bahwa Modified Distribution (MODI) dan Least Cost dapat meminimumkan biaya operasional yang dikeluarkan dalam pendistribusian air. Selajutnya oleh (Addini,2018) Metode Vogel's Approximation (VAM) dan Stepping Stone dapat meminimalisasi biaya distribusi air bersih dan dapat diaplikasikan untuk data pendistribusian air bersih pada PDAM Tirtanadi cabang Sunggal. Pada penelitian ini akan membahas metode North West Corner dan metode Modified Distribution untuk mengoptimumkan biaya distribusi air di PDAM Wae Manurung Kabupaten Bone. 


\section{Metode North West Corner (NWC)}

Algoritma North West Corner yaitu: 1) Tentukan banyaknya daerah persediaan( $i)$ dan daerah permintaan $(j) ; 2)$ Isilah biaya distribusi $(C)$ untuk tiap daerah persediaan $(i)$ dan permintaan $(j)$; $3)$ Isilah unit permintaan per daerah $(b)$ dan unit persediaan per gudang atau persediaan $(a) ; 4)$ Lakukan perbandingan unit persediaan $(a)$.dengan unit permintaan $(b)$. Isilah unit terkecil $(X)$ antara permintaan dan persediaan pada kolom kiri bagian atas; 5) Kolom atau baris pada permintaan atau persediaan yang telah terpenuhi tidak boleh lagi diisi; 6) Pengisian unit $(X)$ berikutnya adalah kolom atau baris kiri atas berikutnya yang belum terisi; 7) Ulangi langkah 5, sampai semua elemen pada table distribusi terpenuhi semua; 8) Biaya per kolom adalah besarnya biaya dikalikan dengan unit yang didistribusikan; dan 9) Total biaya adalah jumlah semua cost per kolom pada langkah 9 (Chandra, 2016).

\section{METODE PENELITIAN}

Penelitian ini adalah penelitian terapan yang dilakukan pada bulan bulan November 2020 Januari 2021 dengan menggunakan data jumlah persediaan air, jumlah permintaan air, dan biaya distribusi air oleh PDAM Wae Manurung Kabupaten Bone yang data tersebut diperoleh pada bulan Juni 2019, yaitu terdapat pada Tabel 1, Tabel 2, dan Tabel 3.

TABEL 1. Jumlah Persediaan Air di Setiap Sumber Air

\begin{tabular}{ccc}
\hline NO & Nama Instalasi & Persediaan Air $\left(\boldsymbol{m}^{\mathbf{3}}\right)$ \\
\hline 1 & Wollangi & 156,906 \\
2 & Panyili & 39,580 \\
3 & Cinnong & 20,991 \\
4 & Barebbo & 31,575 \\
5 & Palattae & 18,409 \\
6 & Patangkai & 34,244 \\
7 & Tanabatu & 34,362 \\
\hline & Total & $\mathbf{3 3 6 , 0 6 7}$
\end{tabular}

(Sumber : PDAM Wae Manurung, Juni 2019)

TABEL 2. Jumlah Permintaan Air dari Setiap Kecamatan

\begin{tabular}{ccc}
\hline NO & Kecamatan & Permintaan Air $\left.\boldsymbol{( m}^{\mathbf{3}}\right)$ \\
\hline 1 & Tanete Riattang & 111,991 \\
2 & Tanete Riattamg Barat & 13,404 \\
3 & Palakka & 8,403 \\
4 & Barebbo & 1,488 \\
5 & Kajuara & 16,523 \\
6 & Kahu & 3,844 \\
7 & Libureng & 3,710 \\
8 & Lamuru & 4,786 \\
9 & Ulaweng & 3,851 \\
10 & Ajangale & 18,304 \\
11 & Amali & 9,956 \\
12 & Lappariaja & 10,015 \\
13 & Mare & 13,026 \\
\hline
\end{tabular}

(Sumber : PDAM Wae Manurung, Juni 2019) 


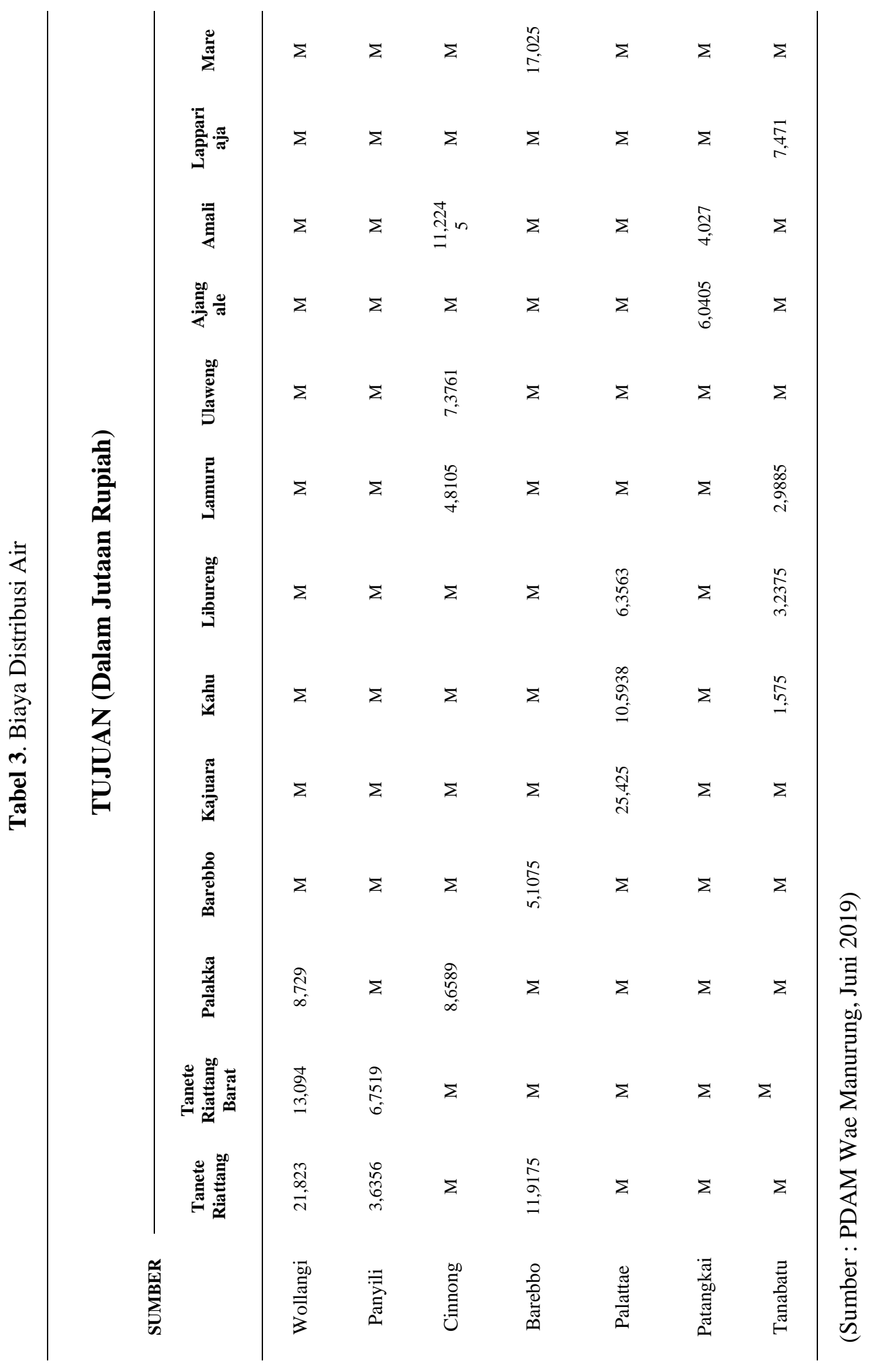




\section{HASIL PENELITIAN DAN PEMBAHASAN}

\section{Formulasi Model Transportasi}

Berdasarkan data pada Tabel $1-3$ dan asumsi jika tidak ada jalur langsung dari sumber air ke wilayah tertentu pelayanan maka biaya transportasinya sebesar M (bilangan positif terbesar) artinya biaya transportasi bisa melebihi dari perkiraan. Alokasi air ke wilayah tersebut $0 \mathrm{~m}^{3}$ diperoleh sebuah Model Transportasi sebagaimana fungsi tujuan pada persamaan (1), fungsi kendala persediaan pada persamaan (2), dan fungsi kendala permintaan pada persamaan (3).

Minimum $Z=\sum_{i=1}^{m} \sum_{j=1}^{n} C_{i j} X_{i j}$

$$
\begin{aligned}
& Z=21,823 X_{11}+13,094 X_{12}+8,729 X_{13}+3,6356 X_{21}+ \\
& 6,7519 X_{22}+8,6589 X_{33}+4,8105 X_{38}+7,3761 X_{39}+ \\
& 11,2245 X_{311}+11,9175 X_{41}+5,1075 X_{44}+17.025 X_{413}+ \\
& 25,425 X_{55}+10,5938 X_{56}+6,3563 X_{57}+6,0405 X_{610}+ \\
& 4,0270 X_{611}+1,575 X_{76}+3,2375 X_{77}+2,9885 X_{78}+7,471 X_{712}
\end{aligned}
$$

dengan fungsi kendala:

persediaan :

$$
\begin{array}{cc}
\qquad \sum_{\mathrm{j}=1}^{13} X_{\mathrm{ij}} \leq 336,067, \mathrm{i}=1,2,3, \ldots, 7 \\
\text { Instalasi Air Wollangi }(\text { untuk } i=1) & \text { Instalasi Air Palattae (untuk } i=5) \\
X_{11}+X_{12}+X_{13} \leq 156,906 & X_{55}+X_{56}+X_{57} \leq 18,409 \\
\text { Instalasi Air Panyili }(\text { untuk } i=2) & \text { Instalasi Air Patangkai }(\text { untuk } i=6 \text { ) } \\
X_{21}+X_{22} \leq 39,58 & X_{610}+X_{611} \leq 34,244 \\
\text { Instalasi Air Cinnong (untuk } i=3) & \text { Instalasi Air Tanabatu (untuk } i=7 \text { ) } \\
X_{33}+X_{38}+X_{39}+X_{311} \leq 20,991 & X_{76}+X_{77}+X_{78}+X_{712} \leq 34,362 \\
\text { Instalasi Air Barebbong (untuk } i=4) &
\end{array}
$$$$
X_{41}+X_{44}+X_{413} \leq 31,575
$$

permintaan :

$$
\sum_{\mathrm{i}=1}^{7} \mathrm{X}_{\mathrm{ij}} \geq 219,301, \mathrm{j}=1,2, \ldots, 13
$$

Kecamatan Tanete Riattang (untuk $j=1$ )

$X_{11}+X_{21}+X_{41} \geq 111,991$

Kecamatan Tanete Riattang Barat(untuk $j=2)$

$X_{12}+X_{22} \geq 13,404$

Kecamatan Palakka (untuk $j=3$ )

$X_{13}+X_{33} \geq 8,403$

Kecamatan Barebbo (untuk $j=4$ )

$X_{44} \geq 1,488$

Kecamatan Kajuara (untuk $j=5$ )

$X_{55} \geq 16,523$

Kecamatan Kahu (untuk $j=6$ )

$X_{56}+X_{76} \geq 3,844$
Kecamatan Lamuru (untuk $j=8$ )

$X_{38}+X_{78} \geq 4,786$

Kecamatan Ulaweng (untuk $j=9$ )

$X_{39} \geq 3,851$

Kecamatan Ajangale (untuk $j=10$ )

$X_{610} \geq 18,304$

Kecamatan Amali (untuk $j=11$ )

$X_{311}+X_{611} \geq 9,956$

Kecamatan Lappariaja (untuk $j=12$ )

$X_{712} \geq 10,015$

Kecamatan Mare (untuk $j=13$ )

$X_{413} \geq 13,026$

Kecamatan Libureng (untuk $j=7$ )

$X_{57}+X_{77} \geq 3,710$ 


\section{Analisa Keseimbangan Model Transportasi}

Berdasarkan data yang diperoleh dari PDAM Wae Manurung Kabupaten Bone mengenai total suplay (unit instalasi air) dan total demand (daerah tujuan), yang ditunjukka pada persamaan (4).

$$
\left.\begin{array}{c}
\sum_{j=1}^{13} X_{i j}, i=1,2,3, \ldots, 7>\sum_{i=1}^{7} X_{i j}, j=1,2, \ldots, 13 \\
336,987>219,301
\end{array}\right\}
$$

\section{Tabel Transportasi}

Suatu model transportasi dapat diselesaikan dengan bantuan tabel transportasi. Berdasarkan persamaan $2-5$ dapat dibentuk sebuah tabel transportasi mengenai pengoptimalan biaya distribusi air di kabupaten Bone oleh PDAM Wae Manurung pada bulan Juni 2019, ditunjukkan pada Tabel 4.

\section{Menentukan Solusi Awal yang Fisibel}

\section{Metode North West Corner (NWC)}

Adapun proses penyelesaian yang dilakukan untuk mendapatkan solusi awal yang fisibel menggunakan metode $N W C$ yaitu dilakukan sebanyak sembilan iterasi. Adapun hasil akhir perhitungan dalam hal pengoptimalan biaya distribusi air oleh PDAM Wae Manurung Kabupaten Bone ditunjukkan pada Tabel 5 sebagai langkah pertama atau iterasi pertama dan Tabel 6 sebagai hasil iterasi kesembilan atau tabel nilai fisibel awal. Prinsip dari metode ini adalah mengisi sel yang berada paling kiri atas. Pada tabel awal yang berada pada sel paling kiri atas adalah sumber Wollangi ke daerah Tanete Riattang, diisi dengan nilai minumum antara total persediaan sumber Wollangi atau total persediaan daerah Tanete Riattang. Maka untuk sell Wollangi ke Tanete Riattang diisi dengan nilai 111,991. Untuk sell seluruh daerah sumber air ke Tanete Riattang tidak diisi lagi karena total dari daerah tujuan Tanete Riattang sudah terpenuhi. Sel yang berada paling ujung kiri selanjutnya yaitu sel sumber Wollangi ke daerah Tanete Riattang Barat diisi seperti pada sel sebelumnya. Hal serupa dilakukan hingga semua sel basis terisi dalam hal ini dilakukan sembilan iterasi. Dan hasil dari metode North West Corner dilihat pada Tabel 6.

Berdasarkan Tabel 6, maka diperoleh solusi awal yang fisibel, ditujukkan pada hasil perhitungan berikut :

$$
\begin{aligned}
Z= & 21,823 X_{11}+13,094 X_{12}+8,729 X_{13}+3,6356 X_{21}+6,7519 X_{22}+8,6589 X_{33}+ \\
& 4,8105 X_{38}+7,3761 X_{39}+11,2245 X_{311}+11,9175 X_{41}+5,1075 X_{44}+17.025 X_{413}+ \\
& 25,425 X_{55}+10,5938 X_{56}+6,3563 X_{57}+6,0405 X_{610}+4,0270 X_{611}++1,575 X_{76}+ \\
& 3,2375 X_{77}+2,9885 X_{78}+7,4712 X_{712} \\
Z= & 21,823(111,9991)+13,094(13,404)+8,729(8,403)+3,6356(0)+6,7519(0)+ \\
& 8,6589(0)+4,8105(4,786)+7,3761(3,851)+11,2245(9,956)+11,9175(0)+ \\
& 5,1075(1,488)+17,025(13,026)+25,425(16,523)+10,5938(1,886)+ \\
& 6,3563(0)+6,0405(18,304)+4,027(0)+1,575(1,958)+3,2375(3,71)+ \\
& 2,9885(0)+7,4712(10,015) \\
Z= & 2444,15636+175,51198+73,349787+0+0+0+23,02305+28,40536+ \\
& 111,75112+0+7,59996+221,76765+420,097275+10,5938(1,886)+0+ \\
& 6,0405(18,304)+0+1,575(1,958)+3,2375(3,71)+0+7,4712(10,015) \\
Z= & 6.550,79
\end{aligned}
$$




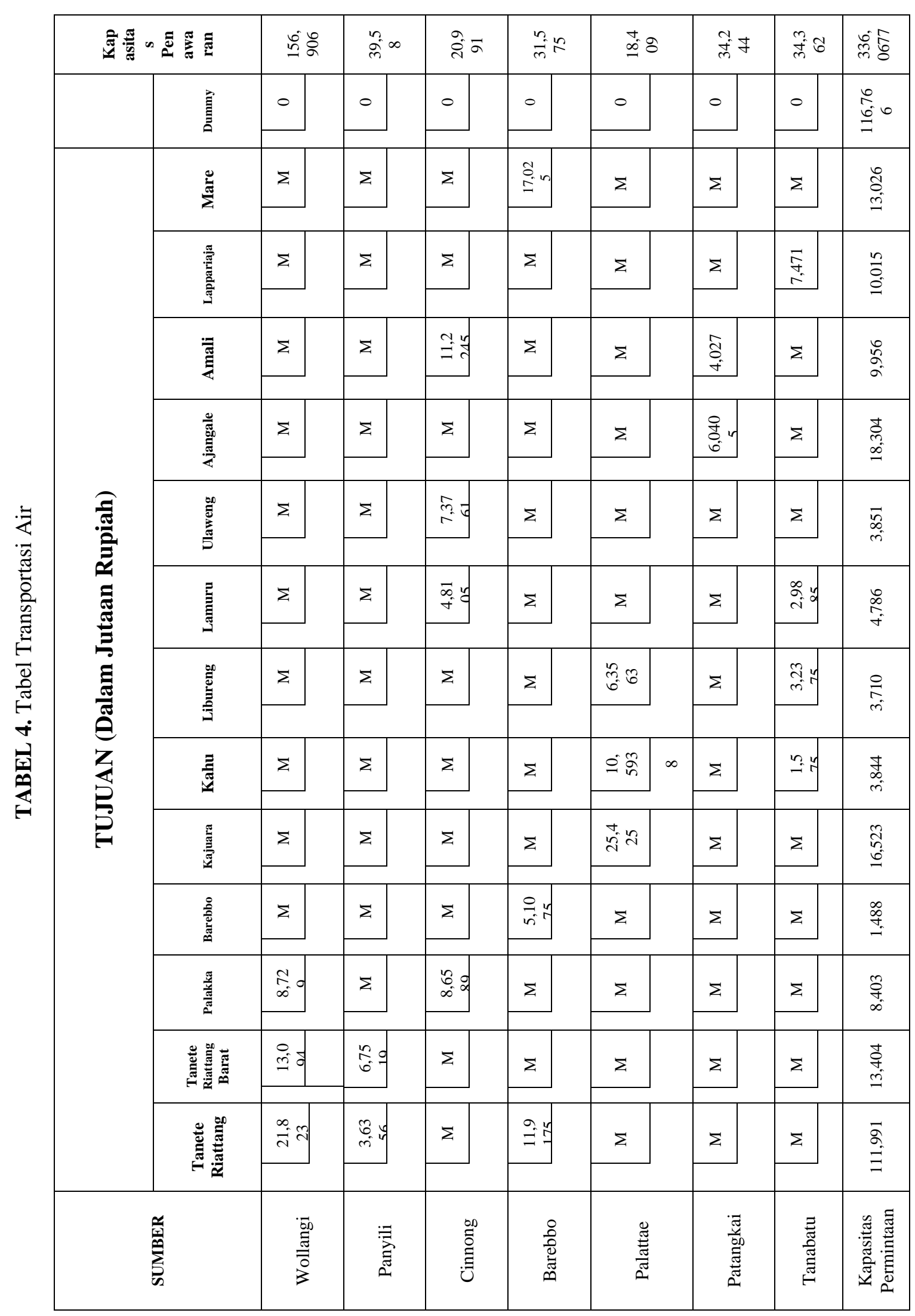




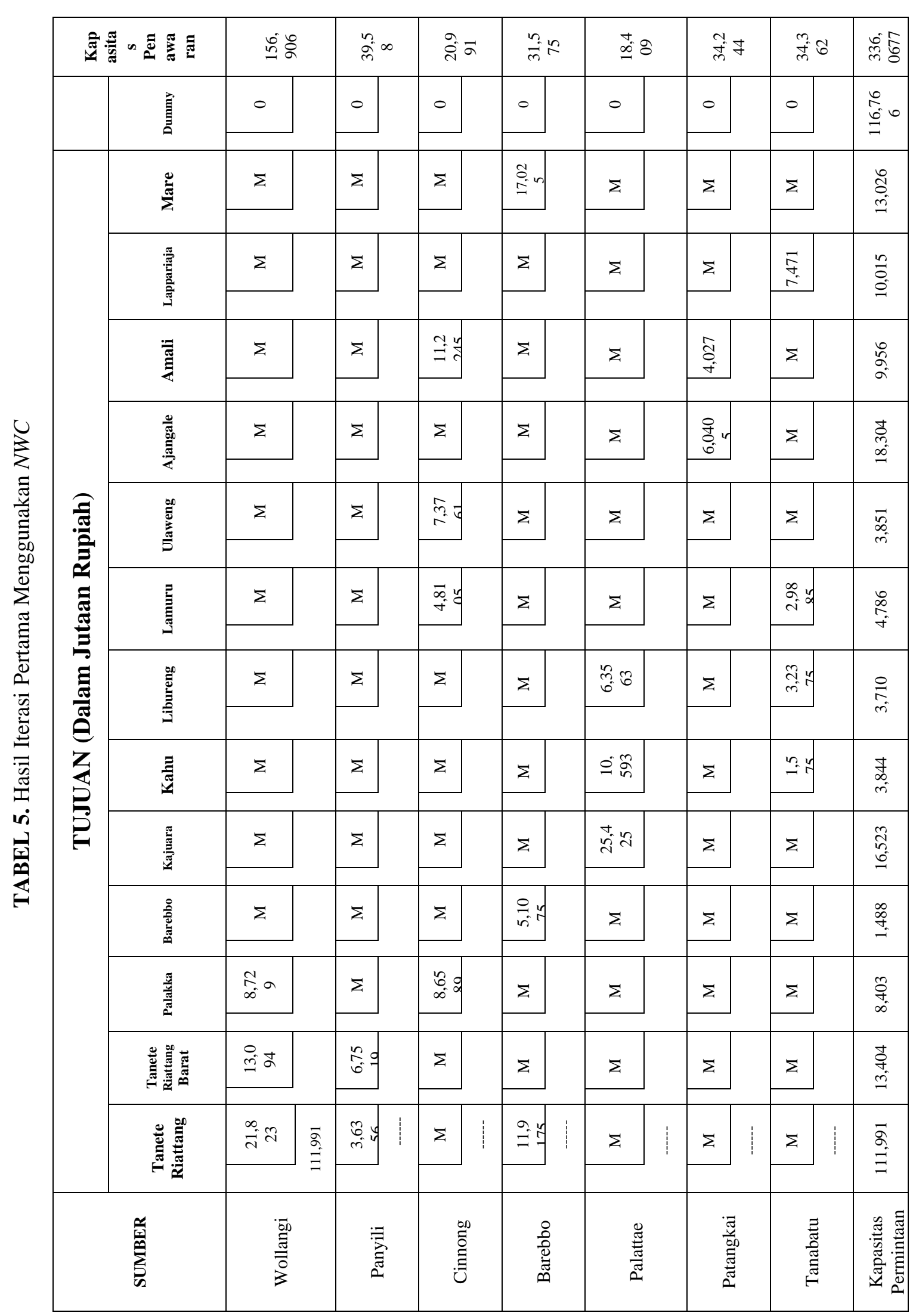




\begin{tabular}{|c|c|c|c|c|c|c|c|c|c|c|c|c|c|c|c|c|c|}
\hline \multirow{16}{*}{ 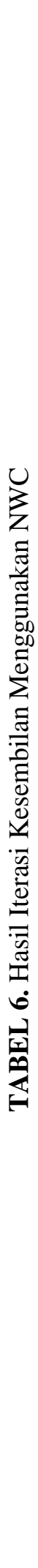 } & \multicolumn{2}{|c|}{ 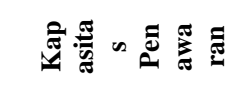 } & \multicolumn{2}{|c|}{ மீ } & \multicolumn{2}{|c|}{$\tilde{n}_{\infty} \infty$} & \multicolumn{2}{|c|}{ 仓ेंन } & \multicolumn{2}{|c|}{$\frac{n}{m}=$} & \multicolumn{2}{|c|}{$\stackrel{+}{\infty} \stackrel{8}{\infty}$} & \multicolumn{2}{|c|}{ 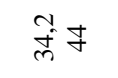 } & \multicolumn{2}{|c|}{$\stackrel{m}{\dot{m}} \mathrm{~N}$} & \multirow{2}{*}{ 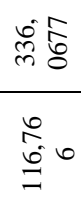 } \\
\hline & \multirow{14}{*}{ 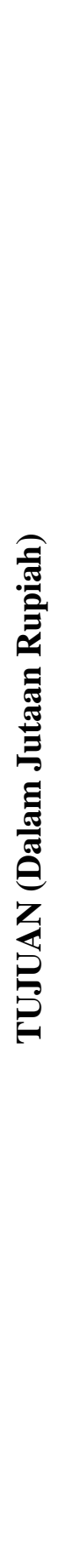 } & 言 & 0 & $\stackrel{\infty}{\frac{\pi}{d}}$ & 0 & $\begin{array}{l}\infty \\
\stackrel{\infty}{n} \\
m^{2}\end{array}$ & 0 & ले & 0 & 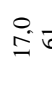 & 0 & & 0 & हे & 0 & $\stackrel{\circ}{\circ}$ 워 & \\
\hline & & 节 & $\Sigma$ & 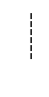 & $\Sigma$ & 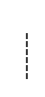 & $\Sigma$ & 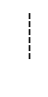 & $\stackrel{s}{s}$ & $\begin{array}{c}\tilde{\sigma} \\
\tilde{c}\end{array}$ & $\Sigma$ & 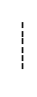 & $\Sigma$ & 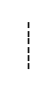 & $\Sigma$ & & 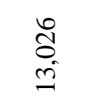 \\
\hline & & 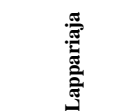 & $\Sigma$ & 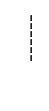 & $\Sigma$ & 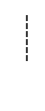 & $\Sigma$ & 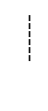 & $\Sigma$ & 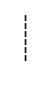 & $\Sigma$ & 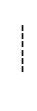 & $\Sigma$ & 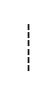 & 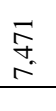 & $\begin{array}{l}n \\
\vdots \\
\stackrel{0}{0}\end{array}$ & $\stackrel{n}{0}$ \\
\hline & & 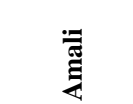 & $\Sigma$ & 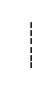 & $\Sigma$ & 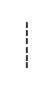 & $\stackrel{ }{=}=$ & $\begin{array}{l}0 \\
\vdots \\
\alpha \\
\sigma\end{array}$ & $\Sigma$ & 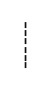 & $\Sigma$ & & $\begin{array}{l}\hat{\hat{o}} \\
\text { + }\end{array}$ & 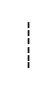 & $\Sigma$ & 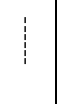 & $\begin{array}{l}\swarrow \\
\alpha\end{array}$ \\
\hline & & 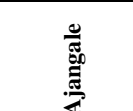 & $\Sigma$ & 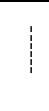 & $\Sigma$ & 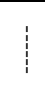 & $\Sigma$ & 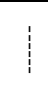 & $\Sigma$ & 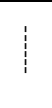 & $\Sigma$ & 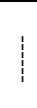 & o & 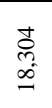 & $\Sigma$ & 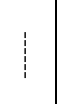 & $\begin{array}{l}\underset{c}{0} \\
\text { D. } \\
\infty \\
-\infty\end{array}$ \\
\hline & & 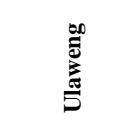 & $\Sigma$ & 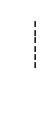 & $\Sigma$ & 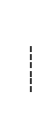 & $\stackrel{\sqrt[m]{2}}{i}$ & $\begin{array}{l}\overrightarrow{\vec{b}} \\
\infty \\
\infty\end{array}$ & $\Sigma$ & 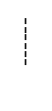 & $\Sigma$ & 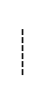 & $\Sigma$ & 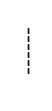 & $\Sigma$ & 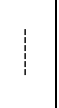 & $\begin{array}{l}\vec{\sim} \\
\infty \\
\dot{m}\end{array}$ \\
\hline & & 氖 & $\Sigma$ & 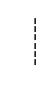 & $\Sigma$ & 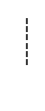 & $\begin{array}{l}\overrightarrow{0} \\
\dot{x}\end{array}$ & 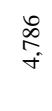 & $\Sigma$ & 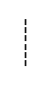 & $\Sigma$ & 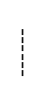 & $\Sigma$ & 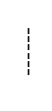 & $\begin{array}{l}\infty \\
\stackrel{i}{c}\end{array}$ & & $\begin{array}{l}\stackrel{\infty}{\infty} \\
\stackrel{+}{f}\end{array}$ \\
\hline & & & $\Sigma$ & 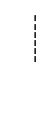 & $\Sigma$ & 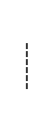 & $\Sigma$ & 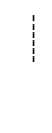 & $\Sigma$ & 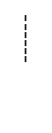 & $\tilde{c}_{0}$ & 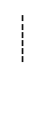 & $\Sigma$ & 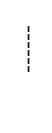 & $\vec{~} \vec{c}$ & $\vec{c}$ & $\stackrel{\circ}{\stackrel{7}{n}}$ \\
\hline & & E్ & $\Sigma$ & 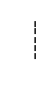 & $\Sigma$ & 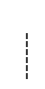 & $\Sigma$ & 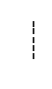 & $\Sigma$ & 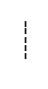 & $0^{\circ}$ is & 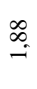 & $\Sigma$ & 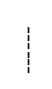 & $\because$ & $\stackrel{\therefore}{\Rightarrow}$ & 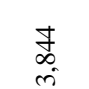 \\
\hline & & " & $\Sigma$ & 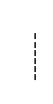 & $\Sigma$ & 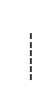 & $\Sigma$ & 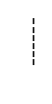 & $\Sigma$ & 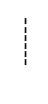 & 苟 & $\stackrel{0}{0}$ & $\Sigma$ & 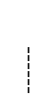 & $\Sigma$ & 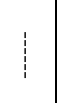 & $\begin{array}{l}\tilde{n} \\
\hat{n} \\
\underline{0}\end{array}$ \\
\hline & & 竧。 & $\Sigma$ & 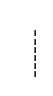 & $\Sigma$ & 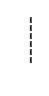 & $\Sigma$ & 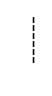 & $\frac{0}{n^{2}}$ & $\stackrel{\infty}{\infty}$. & $\Sigma$ & 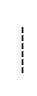 & $\Sigma$ & 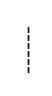 & $\Sigma$ & 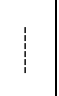 & $\stackrel{\infty}{\stackrel{\infty}{\rightarrow}}$ \\
\hline & & 养 & $\underset{\infty}{N}$ & 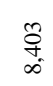 & $\Sigma$ & 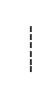 & $\begin{array}{l}b_{0} \\
\infty\end{array}$ & 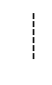 & $\Sigma$ & 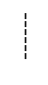 & $\Sigma$ & 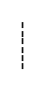 & $\Sigma$ & 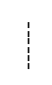 & $\Sigma$ & & $\underset{\substack{\tilde{q} \\
+\infty \\
\infty}}{0}$ \\
\hline & & 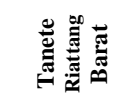 & $\stackrel{0}{g}$ & 荸 & $\begin{array}{l}\stackrel{n}{2}= \\
6\end{array}$ & 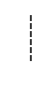 & $\Sigma$ & 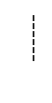 & $\Sigma$ & 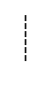 & $\Sigma$ & 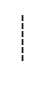 & $\Sigma$ & 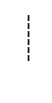 & $\Sigma$ & 1 & 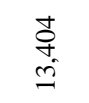 \\
\hline & & 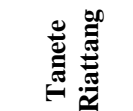 & $\stackrel{\infty}{\vec{\Delta}}$ & $\bar{\sigma}$ & $\hat{\theta}_{i}$ & 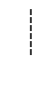 & $\Sigma$ & 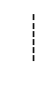 & 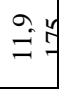 & 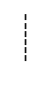 & $\Sigma$ & 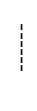 & $\Sigma$ & 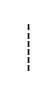 & $\Sigma$ & & $\begin{array}{l}\bar{\Omega} \\
\Xi\end{array}$ \\
\hline & & 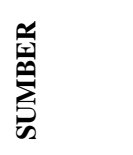 & & & 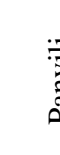 & & 2. & & $\frac{\delta}{d}$ & & $\frac{2}{2}$ & & & & 年 & & 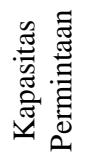 \\
\hline
\end{tabular}




\begin{tabular}{|c|c|c|c|c|c|c|c|c|c|c|c|c|c|c|c|c|}
\hline \multicolumn{2}{|c|}{ 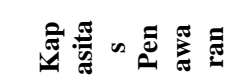 } & \multicolumn{2}{|c|}{ ڤึ̊ } & \multicolumn{2}{|c|}{$\hat{n}^{\infty}$} & \multicolumn{2}{|c|}{ टेने } & \multicolumn{2}{|c|}{$\frac{n}{m}=$} & \multicolumn{2}{|c|}{$\stackrel{+}{\infty} a$} & \multicolumn{2}{|c|}{ 点 } & \multicolumn{2}{|c|}{$\stackrel{m}{m} \mathrm{~S}$} & \multirow{2}{*}{ 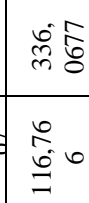 } \\
\hline \multirow{14}{*}{ 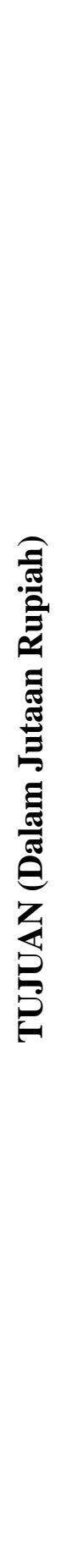 } & 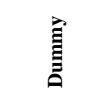 & 0 & $\begin{array}{l}\sqrt{n} \\
\infty \\
\infty \\
\infty\end{array}$ & 0 & 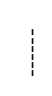 & $\circ$ & $\underset{\substack{\hat{\infty} \\
\hat{\infty}}}{\hat{n}}$ & 。 & 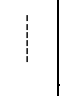 & 0 & $\stackrel{\substack{\infty \\
\rightarrow}}{\rightarrow}$ & $\circ$ & $\begin{array}{l}\infty \\
\stackrel{\circ}{0}\end{array}$ & $\circ$ & & \\
\hline & $\sum_{\Sigma}^{\stackrel{0}{\pi}}$ & $\Sigma$ & 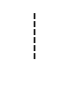 & $\Sigma$ & 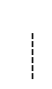 & $\Sigma$ & 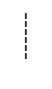 & $\begin{array}{l}\tilde{\delta} \\
\stackrel{-}{=}\end{array}$ & 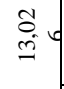 & $\Sigma$ & 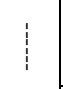 & $\Sigma$ & 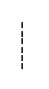 & $\Sigma$ & 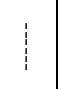 & రి \\
\hline & 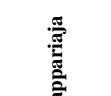 & $\Sigma$ & 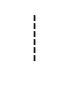 & $\Sigma$ & 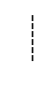 & $\Sigma$ & 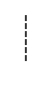 & $\Sigma$ & 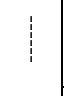 & $\Sigma$ & 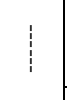 & $\Sigma$ & 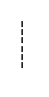 & 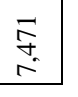 & $\begin{array}{l}n \\
\stackrel{n}{0} \\
\stackrel{0}{=}\end{array}$ & $\begin{array}{l}n \\
\stackrel{0}{0}\end{array}$ \\
\hline & 雳 & $\Sigma$ & 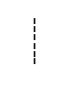 & $\Sigma$ & 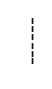 & $\stackrel{2}{=}=$ & 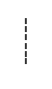 & $\Sigma$ & 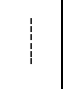 & $\Sigma$ & 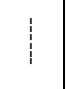 & $\begin{array}{l}\widehat{\hat{\sigma}} \\
\dot{f} \\
\end{array}$ & ڤু & $\Sigma$ & 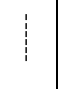 & ஜू \\
\hline & 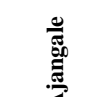 & $\Sigma$ & 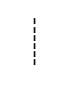 & $\Sigma$ & 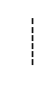 & $\Sigma$ & 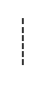 & $\Sigma$ & 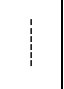 & $\Sigma$ & 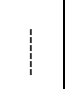 & 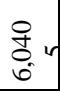 & 呄 & $\Sigma$ & & $\begin{array}{l}\text { d } \\
\substack{\infty \\
\infty}\end{array}$ \\
\hline & $\stackrel{0}{\bar{\nu}}$ & $\Sigma$ & 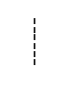 & $\Sigma$ & : & $\stackrel{m}{r}=$ & $\begin{array}{l}\vec{b} \\
\substack{\infty \\
\infty}\end{array}$ & $\Sigma$ & 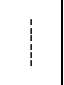 & $\Sigma$ & 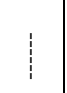 & $\Sigma$ & 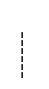 & $\Sigma$ & 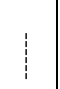 & $\begin{array}{l}\bar{\sigma} \\
\infty \\
\infty\end{array}$ \\
\hline & 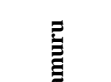 & $\Sigma$ & 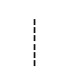 & $\Sigma$ & 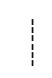 & $\begin{array}{lll}\vec{\infty} & \text { ved } \\
\rightarrow & 0\end{array}$ & 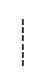 & $\Sigma$ & 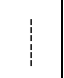 & $\Sigma$ & 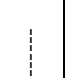 & $\Sigma$ & 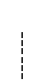 & $\stackrel{\infty}{i}=$ & $\begin{array}{l}\stackrel{\infty}{\infty} \\
\stackrel{+}{+}\end{array}$ & $\stackrel{\infty}{\stackrel{\infty}{\circ}}$ \\
\hline & $\stackrel{n}{\underline{E}}$ & $\Sigma$ & 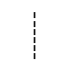 & $\Sigma$ & 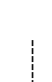 & $\Sigma$ & 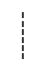 & $\Sigma$ & 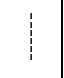 & బ్రి & 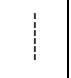 & $\Sigma$ & 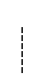 & $\hat{n}^{2}$ & $\vec{r}$ & 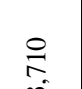 \\
\hline & हี & $\Sigma$ & 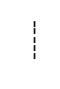 & $\Sigma$ & 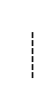 & $\Sigma$ & 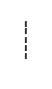 & $\Sigma$ & 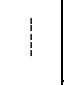 & $\rho$ in & 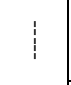 & $\Sigma$ & 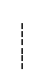 & $\because$ & $\underset{\substack{+c_{i}}}{-1}$ & $\underset{\substack{* \\
\infty \\
\infty}}{\substack{7 \\
\infty}}$ \\
\hline & $\frac{\pi}{3}$ & $\Sigma$ & 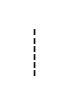 & $\Sigma$ & 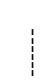 & $\Sigma$ & 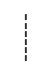 & $\Sigma$ & 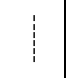 & तु่ & $n$ & $\Sigma$ & 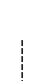 & $\Sigma$ & 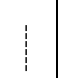 & 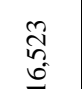 \\
\hline & $\stackrel{0}{\circ}$ & $\Sigma$ & 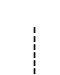 & $\Sigma$ & 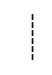 & $\Sigma$ & 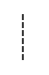 & क्ष & $\stackrel{\infty}{\rightarrow} \infty$ & $\Sigma$ & 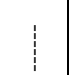 & $\Sigma$ & 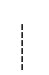 & $\Sigma$ & 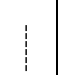 & 文 \\
\hline & $\frac{\mathbb{s}}{\frac{\pi}{\pi}}$ & $\underset{\infty}{\stackrel{N}{\infty}} a$ & 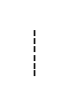 & $\Sigma$ & 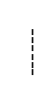 & $\begin{array}{ll}n & 0 \\
\infty & \infty\end{array}$ & $\underset{\infty}{q}, c$ & $\Sigma$ & 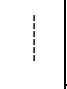 & $\Sigma$ & 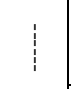 & $\Sigma$ & 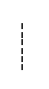 & $\Sigma$ & 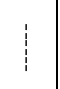 & $\underset{\substack{+\infty \\
\infty}}{\infty}$ \\
\hline & 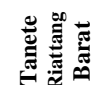 & ले & 孛 & $\begin{array}{ll}n \\
\hat{b}_{0}\end{array}$ & 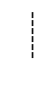 & $\Sigma$ & 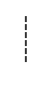 & $\Sigma$ & 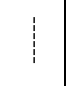 & $\Sigma$ & 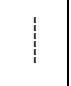 & $\Sigma$ & 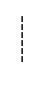 & $\Sigma$ & 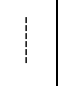 & 荇 \\
\hline & 总 & $\frac{\infty}{i} \pi$ & $\begin{array}{l}n \\
m \\
n \\
n \\
n\end{array}$ & 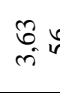 & $\begin{array}{l}\infty \\
\cdots \\
\tilde{m}\end{array}$ & $\Sigma$ & 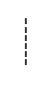 & $=0$ & : & $\Sigma$ & 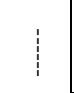 & $\Sigma$ & 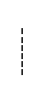 & $\Sigma$ & 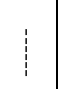 & $\vec{\sigma}$ \\
\hline & t) & $\begin{array}{l}\overrightarrow{0} \\
\text { 흘 } \\
\overline{0}\end{array}$ & & 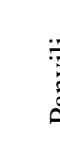 & & 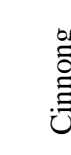 & & 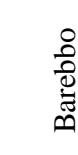 & & 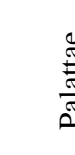 & & s & & 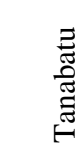 & & 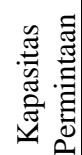 \\
\hline
\end{tabular}




\section{Menentukan Solusi Optimum}

Menentukan solusi optimum menggunakan Metode Modified Distribution (MODI) dengan nilai fisibel awal dari metode North West Corner. Adapun langkah pertama yakni mencari setiap indeks dari setiap baris (U) dan kolom (U) dari tabel nilai fisibel awal. selanjutnya adalah menghitung perubahan biaya untuk setiap variable non basis dengan formula $C_{i j}{ }^{\prime}=C_{i j}-U_{i}-$ $V_{j}$, dan jika terdapat $C_{i j}{ }^{\prime}$ bernilai negatif maka solusi belum optimum. Selanjutnya $X_{i j}$ dengan nilai $C_{i j}{ }^{\prime}$ negatif terbesar sebagai entering sel dan mengalokasikan sejumlah nilai dari entering sel sesuai dengan proses Stepping Stone. Sehingga diperoleh iterasi pertama dengan menggunkan metode Modified Distribution. Dengan cara yang sama dilanjutkan sampai semua nilai $C_{i j}^{\prime}$ bernilai positif berdasarkan algoritma dari metode Modified Distribution sehingga diperoleh solusi optimum dengan melakukan enam kali iterasi dan dapat dilihat pada Tabel 7.

Berdasarkan Tabel 7, maka diperoleh solusi optimum, ditujukkan pada hasil perhitungan berikut:

$$
\begin{aligned}
Z= & 21,823 X_{11}+13,094 X_{12}+3,6356 X_{21}+8,6589 X_{33}+7,3761 X_{39}+11,9175 X_{41}+ \\
& 5,1075 X_{44}+17,025 X_{413}+12,412 X_{55}+6,0405 X_{610}+4,027 X_{611}+1,575 X_{76}+ \\
& 3,2375 X_{77}+2,9885 X_{78}+7,471 X_{712} \\
Z= & 21,823(55,35)+13,094(13,404)+3,6356(39,58)+8,6589(8,403)+ \\
& 7,3761(3,851)+11,9175(17,061)+5,1075(1,488)+17,025(13,026)+ \\
& 12,412(16,523)+6,0405(18,304)+4,027(9,956)+1,575(3,844)+3,2375(3,71)+ \\
& 2,9885(4,786)+7,471(10,015) \\
Z= & 1207,90305+175,511976+143,897048+72,7607367+28,4053611+ \\
& 203,3244675+7,59996+221,76765+420,097275+110,565312+40,092812+ \\
& 6,0543+12,011125+14,302961+74,822065 \\
Z= & 2739,116099
\end{aligned}
$$

\section{KESIMPULAN}

Berdasarkan hasil penelitian yang telah diuraikan, diperoleh kesimpulan sebagai berikut:

1. Langkah optimasi pendistribuisan air menggunakan Metode Modified Distribution yang diawali dengan nilai fisibel awal dengan menggunakan Metode North West Corner di PDAM Wae Manurung Kabupaten Bone yaitu dengan model transportasi distribusi air berdasarkan data distribusi air oleh PDAM Wae Manurung Kabupaten Bone pada Bulan Juni 2019 yang menghasilakan fungsi tujuan dan fungsi kendala. Model Transportasi diterapkan untuk optimasi biaya distribusi dengan solusi awal yang fisibel dengan menggunakan Metode North West Corner sebanyak 9 iterasi. Selanjutnya ditentukan solusi optimum menggunakan Metode Modified Distribution sebanyak 6 iterasi.

2. Hasil optimasi pendistribuisan air menggunakan Metode Modified Distribution yang diawali dengan nilai fisibel awal dengan menggunakan Metode North West Corner di PDAM Wae Manurung Kabupaten Bone memberikan hasil optimum sebesar Rp2.739.116.099. Sehingga terjadi penghematan biaya distribusi air sebesar 52,22\% dari biaya distibusi awal (sebesar Rp5.732.709.219 yang dikeluarkan oleh PDAM Wae Manurung Kabupaten Bone) atau Rp2.993.593.120.

\section{DAFTAR PUSTAKA}

Addini, P. F. (2018). Aplikasi Metode Vogel's Approximation dan Stepping Stone dalam Meminimalisasi Biaya Distribusi Air Bersih pada PDAM Tirtanadi Cabang Sunggal. (Skripsi). Universitas Sumatera Utara, Medan. 
Aisyah, Ika, P., \& Yuki, N.N. (2018). Penerapan Metode Vogel's Approximation Method (VAM) dan Modified Distribution (MODI) Dalam Penyelesaian Transshipment Problem. Jurnal EKSPONENSIAL, 9(2). 187 - 196.

Asyhari, M.N.A. (2018). Model Transportasi dan Penerapannya Dalam Mengoptimalkan Biaya Distribusi Beras Miskin Kota Makassar Oleh Perum Bulogsub Divre Makassar Tahun 2016. (Skripsi). Universitas Negeri Makassar, Makassar.

Chandra, T. (2016). Penerapan Algoritma North West Corner Dalam Penyelesaian Masalah Transportasi. Jurnal TIMES, V(1). 12 - 16.

Dedhy, A. (2019). bonepost.com. Diambil kembali dari https://www.bonepos.com: https://www.bonepos.com/2019/12/03/krisis-air-bersih-di-bone-pdam-diminta-carisolusi diakses pada tanggal 23 Oktober 2020.

Hammer, I. (2020). Beranda NKRI News. Retrieved from berandankrinews.com: https://www.berandankrinews.com/2020/05/08/pdam-bone-mohon-maaf-kepadaseluruh-pelanggan-air-kota-watampone-atas-tidak-mengalirnya-air-karena-pipatransmisi-wollangi-sedang-dalam-perbaikan/diakses pada tanggal 23 Oktober 2020.

Nelwan, C., Jhon S.K., \& Yohanes L. (2013). Optimasi Pendistribusian Air dengan Menggunakan Metode Least Cost dan Metode Modified Distribution (Studi Kasus: PDAM Kabupaten Minahasa Utara). Jurnal Ilmiah Sains, 13(1). 45 - 51.

Trisna, A. (2018). Desember 10. Global Terkini. Diakses dari dari www.globalterkini.com: https://www.globalterkini.com/2018/12/polemik-soal-tarif-pdam-bone-hmi-mintadirekturnya-dicopot.html pada tanggal 23 Oktober 2020.

Zulkarnaen, W. (2020). Evaluasi Kinerja Distribusi Logistik Kpu Jawa Barat Sebagai Parameter Sukses Pilkada Serentak 2018. Jurnal Ilmiah MEA, 4(2). 244-264. 